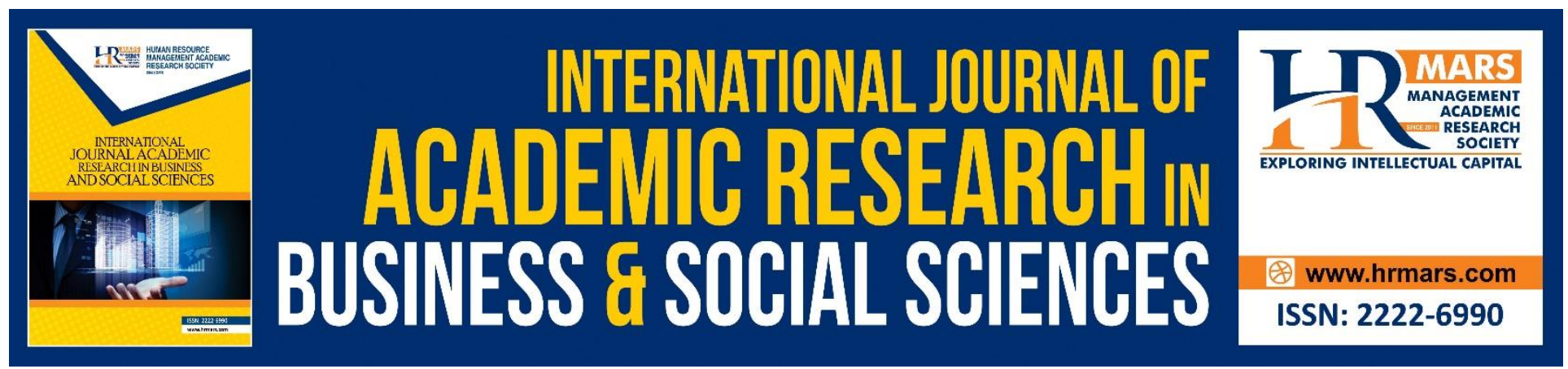

\title{
Youth and Disaster Management in Malaysia
}

\section{Haliza Abdul Rahman}

To Link this Article: http://dx.doi.org/10.6007/IJARBSS/v10-i16/8318

DOI:10.6007/IJARBSS/v10-i16/8318

Received: 16 September 2020, Revised: 20 October 2020, Accepted: 18 November 2020

Published Online: 30 November 2020

In-Text Citation: (Rahman, 2020)

To Cite this Article: Rahman, H. A. (2020). Youth and Disaster Management in Malaysia. International Journal of Academic Research in Business and Social Sciences, 10(16), 367-380.

\section{Copyright: (c) 2020 The Author(s)}

Published by Human Resource Management Academic Research Society (www.hrmars.com)

This article is published under the Creative Commons Attribution (CC BY 4.0) license. Anyone may reproduce, distribute, translate and create derivative works of this article (for both commercial and non-commercial purposes), subject to full attribution to the original publication and authors. The full terms of this license may be seen at: http://creativecommons.org/licences/by/4.0/legalcode

Special Issue: Youth and Community Wellbeing: Issues, Challenges and Opportunities for Empowerment V2, 2020, Pg. 367 - 380 http://hrmars.com/index.php/pages/detail/IJARBSS JOURNAL HOMEPAGE

Full Terms \& Conditions of access and use can be found at http://hrmars.com/index.php/pages/detail/publication-ethics 


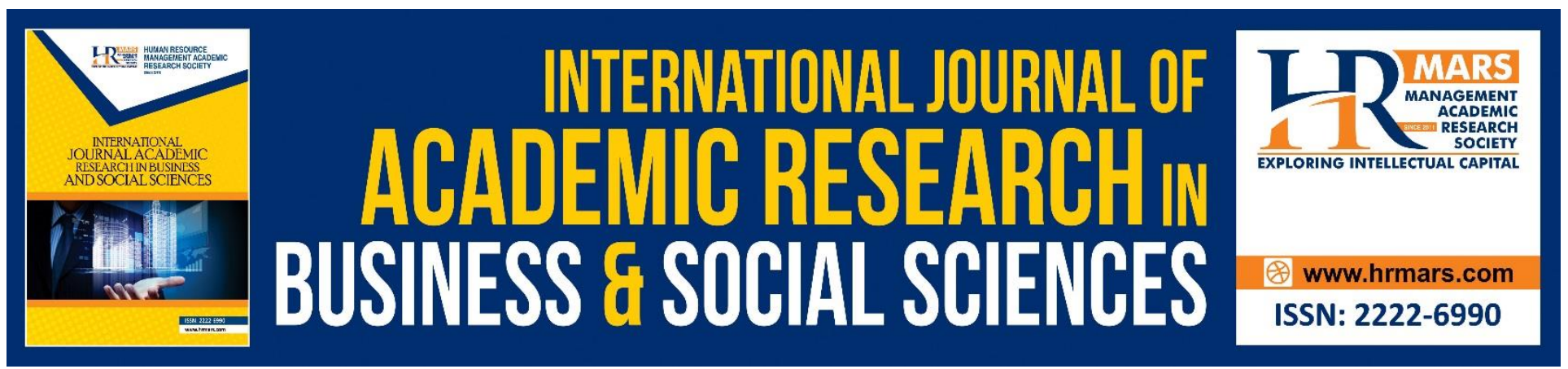

\title{
Youth and Disaster Management in Malaysia
}

\author{
Haliza Abdul Rahman \\ Institute for Social Science Studies, Putra Infoport, Universiti Putra Malaysia, 43400 Serdang, \\ Selangor, Department of Environmental and Occupational Health, Faculty of Medicine and Health \\ Sciences, Universiti Putra Malaysia, 43400 UPM Serdang, Selangor \\ Email: dr.haliza@upm.edu.my
}

\begin{abstract}
Introduction: Malaysia is facing increasing exposure to disaster risk. In the last two decades from 1998 until 2019, Malaysia also has experienced 51 natural disaster events, with 281 deaths, over 3 million people affected, and damages worth nearly US\$2 billion (MYR8 billion). Thus, disaster management has become a significant concern of the Malaysian government. Two examples of environmental disasters in Malaysia have been discussed. Objective: The objective of this paper is to highlight the importance of youth involvement in disaster risk management, identify strategies to effectively involve them in disaster risk management as well as the describe the current roles of the Malaysian youth in disaster risk management. Method: This review was carried out using secondary data collected from multiple sources on the topic roles of youth in disaster preparedness, risk reduction, and management from the year of 2008-2018. Result: With the considerable youth population in Malaysia, youths of today must be empowered with the knowledge needed to cope with the adverse effects of natural disasters. Furthermore, they are physically strong, mentally agile, and look for change and dynamism in their own lives and their communities. They also embody power and strength, are idealistic, and accept new ideas and views without much hesitation. Therefore, youth could play an essential role in disaster risk reduction and management to decrease the number of victims and casualties. Conclusion: Youth are the best people to participate in disaster management issues because they are invaluable human resources of every nation.
\end{abstract}

Keywords: Youth, Empower, Youth Involvement, Cope, Disaster Risk and Management, Malaysia

\section{Introduction}

Disasters are one of the most critical problems in the world today because they are usually unpredictable and can happen at any time, to anyone. A disaster can be defined as a hazardous incident caused by either natural, human-made, or human-made technological error that causes severe physical damage or destruction, loss of life, casualties, or other adverse health impacts. It can lead to damage to property and destruction of the entire area or an environmental system like the 
economic, cultural, and social life of people (Castro, 2013). In short, disaster is tantamount to tragedy, catastrophe, calamity, or devastation (Aini and Ahmadun, 2017).

According to the United Nations Secretariat of the International Strategy for Disaster Reduction (UNISDR 2011), the world is facing increasing exposure to disaster risk. Over time, there has been an increase in the frequency and intensity of disasters - geological, hydro-meteorological, and human-made - due to a rise in vulnerabilities arising from population growth, unplanned urbanization, climate change, and environmental degradation (UNISDR, 2011).

There have been 4,130 disasters arising from natural hazards across the globe resulting in $1,117,527$ deaths and at least US\$1,195 billion recorded in losses. Over the past 30 years, there has been an increase in the proportion of world population living in flood-prone river basins by $114 \%$ and a $192 \%$ increase in the proportion of world population living in cyclone-exposed coastlines. Over $50 \%$ of the world's large cities, with people between 2 million to 15 million, are in areas highly vulnerable to seismic activity, and rapid urbanization will further increase this exposure to disaster risk. Furthermore, all countries experience an increased risk of both natural and human-made disasters, which pose a threat to lives and development efforts. There is also an increasing loss of economic assets, wealth, and livelihoods from disasters that have negatively affected economic growth both locally and globally (UNISDR, 2011).

Between 1991 to 2000, Asia accounted for $83 \%$ of the population affected by disasters worldwide. In Asia, around $24 \%$ of the deaths due to disasters which occur in India because of size, large population, and vulnerability. The high levels of risks, the low levels of local capacity to manage the hazards, lead to a significant loss of lives, property, and livelihoods (UNDP, 2002; Ghani \& Shahdan, 2016)

Therefore, disaster management has become a significant concern of governments in many countries, including Malaysia, and the different levels of governments need to focus more on preparing, presenting, and responding to disasters rather than rehabilitation and reconstruction, due to its high costs. For a community to be disaster resilient, five pillars are needed; Governance, Risk assessment, Knowledge and education, Risk management and vulnerability reduction, and Disaster preparedness and response (Oddsdottir, Lucas, and Combaz, 2013). Additionally, the potential disaster victims have a right the following; Education, training, and skills in disaster management operations; Getting information in writing and orally on disaster management policy; Participation in planning, process, and maintenance program that provides health services including psychosocial support; Participation in decision-making on disaster management, particularly concerning themselves and the community; Supervision following the mechanisms set for the implementation of disaster management (Ali et al., 2019).

These strategies highlight the need for collective efforts at all levels to reduce the number and effects of natural disasters. Disaster risk reduction is not the sole responsibility of governments, but the combined efforts of different stakeholders; hence partnerships with all stakeholders are essential. Without adequate involvement and participation by other stakeholders such as NonGovernmental Organizations and Youth-based organizations, the efforts of governments will remain unsuccessful (Henry and Gireesan, 2011). Community-Based Disaster Management is a practical disaster management approach that ensures active response, involvement, and participation of the local community in planning, decision making, and operationalization of various disaster 
management activities in disaster management. It is, therefore, imperative to raise awareness and build the capacity of the local community in addressing disaster situations (Huq, 2016).

This is especially important in Southeast Asia, the most disaster-prone region in the world, where climate change and disasters are matters of grave and urgent concerns. With an increase in the occurrence of disasters in this region, it is crucial to recognize that disaster management requires the active participation of community members, including the youth, to mitigate and manage the impact of disasters effectively. The youth is an essential sector as they form a third of ASEAN's total population; hence their talents and skills can be utilized for adaptation, mitigation, and disaster resilience activities.

Therefore, in the 10th ASEAN Ministerial Meeting on Youth (AMMY) 2017, the ASEAN youth were encouraged to become more active in ensuring increased inclusiveness and tolerance towards more peaceful, resilient societies for the well-being of ASEAN citizens, as well as the youth. They were also asked to improve awareness of environmental issues among the youth and to strengthen their responsible participation and significant representation in addressing climate change and disaster risks (ASEAN Ministerial Meeting on Youth, 2017). Likewise, the new 2015 - 2030 Sendai Framework for Disaster Risk Reduction adopted at the 3rd UN World Conference on Disaster Risk Reduction acknowledges the vital role of the youth in reducing disaster risk, strengthening community resilience, and shaping legislation for improved protection against disasters. This framework, if effectively implemented in Disaster Risk Reduction (DRR), will create a sustainable and brighter future (UNISDR, 2015).

Considering the above, disaster risk is best reduced through proactive, comprehensive, and systematic efforts from young people in the community (UNISDR 2011). Therefore, young people, especially youth, are encouraged to participate in DRR. This was seen during the Third UN World Conference on DRR in 2015, where 200 young professionals and students from different countries were brought together to exchange ideas and knowledge on DRR (UNISDR, 2015).

Young people are invaluable human resources of a nation, and it is critical that they actively participate in and are involved in disaster issues. Today, more than ever, they are change-makers, building new realities for themselves and their communities. Globally, young people are innovative and agents of social change, who advocate for their fundamental human rights and freedoms and seek new opportunities that enable a better future for themselves and others. Their role in society is crucial because they are young, full of energy, and educated, with rationality as their ultimate belief. Moreover, with their fresh energy, they can perform better and ensure the growth of society (Henry and Gireesan, 2011).

For all these reasons, involving youth in disaster planning and recovery can increase their awareness of the potentially hazardous situations in their neighbourhoods and provide them with knowledge on the best responses for different emergencies. The objectives of this review was therefore carried out to highlight the importance of youth involvement in disaster risk management, identify strategies to effectively involve them in disaster risk management as well as the describe the current roles of the Malaysian youth in disaster risk management. This information will be a resource to governments, agencies, academicians, and environmentalists in Malaysia and around the world by providing knowledge on youth involvement in disaster risk management. 
INTERNATIONAL JOURNAL OF ACADEMIC RESEARCH IN BUSINESS AND SOCIAL SCIENCES

Vol. 10, No. 16, Youth and Community Wellbeing: Issues, Challenges and Opportunities for Empowerment V2. 2020, E-ISSN: 2222-6990 @ 2020 HRMARS

\section{Methods}

This review was carried out using secondary data collected from related multiple sources on the topic roles of youth in disaster preparedness, risk reduction, and management such as journals, conference proceedings, books, reports from governmental and non-governmental organizations, newspapers, and website resources from the year of 2008 until 2019.

\section{Discussion}

\section{Definition of Youth}

Youth refers to young people. However, "Youth" is best understood as a period of transition from a child's dependence to an adult's independence and a period of the awareness of their interdependence as members of a community. According to UNESCO, "youth" means "every person between the ages of 15 and 35 years." Meanwhile, the United Nations, for statistical consistency across regions, defines 'youth', as those persons between the ages of 15 and 24 years (UNESCO, 2019).

In Malaysia, the 1997 National Youth Development Policy defines youth as ranging between the ages of $15-40$ years. However, in the policy, it was stated that youth development programs and activities should be carried out among youth aged $18-25$ years (Ministry of Youth and Sports, 1997). In 2018, the Malaysian government introduced a new definition of youth in Malaysia as ranging between the age group of 15 years to 30 years. The Youth Societies and Youth Development Act 2007 (Act 668) was gazetted to cover issues related to youth development. In the Act, youth was defined as a person, not less than 15 years and not more than 40 years old (Yeon et al., 2016).

\section{Malaysian Youth}

Malaysia has a significant proportion of young people. In 2000, there were 10.1 million people aged 15 to 40 years in Malaysia, a 2.7 million increase since 1991. In 2014, the Malaysian youth population reached 13.67 million. It increased to 13.88 million in 2018, with the age group of 15 - 35 years making up about $45.8 \%$ of Malaysia's total population, the largest among all the age groups. The youth play crucial roles in Malaysia as the backbone of the nation, drivers of change in a society's potential economic force, and as consumers and producers shaping the future.

As a result, they have a critical role to play in the country's effort to become a developed country by 2020, as stated in Malaysia's development plan, known as Vision 2020. It aims to develop all aspects (including social justice and cohesion, economy, and quality of life) of the country by 2020 (United Nations, 2002).

\section{Disasters in Malaysia}

Disasters are a part of human life. However, partly due to climate change, there has been an increase in Malaysia's exposure to floods, flash floods, landslides, and strong winds. Some of these disasters can be predicted; however, several disasters occur without any warning signs. When disasters occur, they do not only result in the loss of life and property, but also cause a range of economic, social, political, and psychological problems that are not easy to overcome (Ali et al., 2019).

Overall, Malaysia has experienced 51 natural disaster events in the last two decades (1998August 2018), with 281 deaths, over 3 million people affected, and nearly US\$2 billion (MYR8 billion) in damages (ReliefWeb, 2019). Most of the carnage in Malaysia have been caused by floods, making 
up 38 out of the total 51 natural disasters between 1998 to 2018, more than the global average of 43 percent. Floods account for the most frequent and significant damage annually and cause a considerable number of loss of human lives, disease epidemics, property and crop damage, and other losses. Between 2012 to 2019, Malaysia accounted for the highest proportion of the population from the ASEAN member states exposed to floods (ReliefWeb 2019). Over the past two decades, floods have affected over 770,000 people, killing 148 people and causing damages worth US\$1.4 billion (MYR5.82 billion) (Zurairi, 2018). Additionally, on June 5th, 2015, a 6.0-moment magnitude earthquake (the strongest earthquake in Malaysia since 1976) struck Ranau, Sabah. The earthquake resulted in damages to buildings and infrastructure, along with geological changes and landslides. About 137 climbers were stranded, with 18 deaths reported (Shah et al., 2018). There are 2 case study conduct by the researcher regarding to the youth and disaster management in Malaysia.

\section{Malaysia's Response to Disasters}

Disaster management has always been a focus of the Malaysian government. As an example, Malaysia's 11th version of the Five-Year Plan (2016 - 2020) aimed to strengthen disaster risk management across the five phases of prevention, mitigation, preparedness, response, and recovery. The plan also incorporated several strategies and implemented a framework to mitigate disaster threats with planned economic and civil progress. It identified disaster management resilience against climate change and natural disaster strategies. In 2015, the National Disaster Management Agency (NADMA) became the lead disaster management agency for regional and international disaster management efforts (CEDMHA, 2016).

Malaysia also continues to develop its disaster management structure and policies to meet emerging and chronic disaster risks. The National Security Council (NSC) coordinates disaster management. It facilitates activities implemented by the Disaster Management and Relief Committee, which is composed of various agencies at federal, state, and local levels (CEDMHA, 2016).

Malaysia continues to emphasize disaster risk reduction by ratifying the Sendai Framework for Disaster Risk Reduction (2012 - 2030) in the Mid-term Review of the Eleventh Malaysia plan (2016 - 2020).

\section{The Need for Youth Involvement in Disaster Risk Management}

Youth development is defined as "...the ongoing growth process in which all youth are engaged in attempting to (1) meet their basic personal and social needs to be safe, feel cared for, be valued, be useful, and be spiritually grounded, and (2) to build skills and competencies that allow them to function and contribute in their daily lives" (Pittman, 1993) including in disaster management issues.

Youth as an asset has to be provided with the essential skills needed to participate in disaster management activities. Through their participation in community activities, they can promote resilience and organize young people's groups that can act as a source of psychosocial support (Manikande, Detcanamurthy and Joseph, 2019). The youth can also teach their communities about risk reduction activities and the impact of disasters. They have an ability unmatched by any demographic group to bring about meaningful change in social behavior and attitudes. Thus, their potential to make a real difference in the time of disasters must not be underestimated (IFRC, 2011).

They an invaluable human resource of a nation because they are physically and mentally agile, embody power and strength, are idealistic, and accept new ideas and views without much hesitation. 
Their impulsiveness provides them with the ability to carry out what they consider essential to themselves and society (Henry and Gireesan, 2011). Thus, their dynamism, energy level, the pace of work, innovative ideas and approaches, and leadership qualities need to be adequately channelled into socially useful and constructive activities. Globally, young people are a force for change, asserting themselves as agents with a powerful voice in the public scene (Ministry of Youth Affairs and Sports, Government of India, 2017b). Hence, youth, in whatever capacity, have an essential role to perform in disaster management (Henry and Gireesan, 2011).

Youth involvement in prevention, preparedness, recovery, and response efforts can help to increase disaster preparation and response efforts of their families and communities. Youth can educate communities about disasters and teach them coping mechanisms before, during, and after a disaster. This can, to a small extent, minimize the panic and chaos that occurs during disasters. Then if there is a disaster, they can protect themselves as well as others. It is thus the responsibility of the nation to utilize such powerful resources of the country by providing them with excellent disaster training and social service awareness, as well as management roles in rehabilitation and post-disaster reconstruction.

Studies show that young people participating in various activities before, during, and after a disaster or a significant incident have a better ability to handle the situation practically and mentally. Young people who participated in various risk management and risk reduction programs demonstrate better knowledge and understanding of security issues and measures. They also actively promoted better preparedness in their surroundings and home environment (Finnis et al., 2010).

Additionally, young people are often severely affected when disasters strike and can face severe difficulties in coping with unexpected and traumatic interruptions in their lives. Thus, they have a right to participate in decisions and efforts addressing disaster management and risk reduction and protecting them from hazards and vulnerabilities (Plan International, 2011).

Globally, young people aged 15 to 24 years comprise nearly 16 percent of the world's population (United Nations, 2019). Therefore, the involvement of today's youth in environment and development decision-making and the implementation of any related programs is critical to the longterm success of disaster risk reduction programs because it affects their lives both in the present and in the future. Hence, an essential objective of empowering the public and the youth is to reduce loss due to disasters (UNEP, 2017).

Moreover, youth possess unique strengths and skillsets, which are enhanced by community support and collaboration. Compared to adults, youth are often trained in public speaking, journalism, and communication. They have better connections to social media and better access to information that help them connect to larger audiences and influence their peers (Ministry of Youth Affairs and Sports, Government of India, 2017a).

Young people are already exposed to several environmental hazards like low air and water quality, high levels of pollution, deforestation, and many more. Thus, they feel a sense of responsibility to protect themselves and their surroundings from the negative impacts of the environment (Ministry of Youth Affairs and Sports, Government of India, 2017b). 
INTERNATIONAL JOURNAL OF ACADEMIC RESEARCH IN BUSINESS AND SOCIAL SCIENCES

Vol. 10, No. 16, Youth and Community Wellbeing: Issues, Challenges and Opportunities for Empowerment V2. 2020, E-ISSN: 2222-6990 @) 2020 HRMARS

\section{Roles of Youth in Disaster Preparedness, Risk Reduction, and Management}

In 2015, members of the United Nations, including Malaysia, agreed upon the Sustainable Development Goals (SDGs). These goals, when met, will shape the world and will thus require the involvement of all individuals and institutions, especially young people, to become a reality.

Youth are at the center of this development plan because they have the potential to be a positive force for transformational change. Hence, youth are increasingly acting as agents of change in their communities by deviating from being the beneficiaries of development work to leaders of impactful, sustainable development initiatives (Ministry of Youth Affairs and Sports, Government of India, 2017b).

They can be key actors in preparedness programs and recovery efforts. They can play such roles as assisting parents and communities in preparing for a disaster or mapping their risk and protective factors. They can also be leaders of disaster preparedness programs and share information on disaster preparedness (Ronan et al., 2015).

They also play essential roles in disaster risk reduction and management. These include taking immediate actions during emergencies due to their high physical energy and helping others prepare for and respond to emergencies. For instance, Saeeda Bibu, a 25-year old volunteer at Red Cross Red Crescent, saved lives in an earthquake in Pakistan in 2005 by assisting the injured victims. She also provided survivors with water and blankets. She, along with other youth volunteers who were trained community disaster educators, rescued schoolchildren, and other people from collapsed homes (Yter, 2007).

The resilience of the youth also helps them adapt to changes, overcome difficulties, including disasters. They are also creative people who can come up with innovative and resourceful ideas for disaster preparedness efforts (Bartlett, 2008).

Involving young people in disaster management can help them learn topics that affect their lives while providing them with a hands-on experience designed to equip them to initiate plans and become better leaders in the future.

An example can be seen among the youth volunteers of the Armenian Red Cross Society who have proven that youths' potential in leadership and plan initiation should not be underestimated. Their youth volunteers initiated a "Clean Sevan" project, which lasted for six years (from 2000 - 2006). They were aimed at cleaning the shores of Lake Sevan and calling the public's attention to the lake's ecological problems. Not everyone welcomed the initiative because the project was assumed to be too ambitious for the youth. However, the project was successfully implemented (Cebu, 2015).

\section{Strategies to Involve Youth in Disaster Management}

Crises and disasters cannot be avoided, but their consequences can be mitigated by planning, exercises, and preparedness (Khorram-Manesh et al., 2016). Although these events affect whole societies, their impact on vulnerable groups is more evident. Children and youth belong to this group and need to be considered for outstanding planning and education (Ronan et al., 2015).

There is a shortage of youth volunteers in disaster mitigation because of knowledge, attitude, and behavior deficit among the youth. While many individuals report that they are aware of disasters and their potential effects, fewer report that they have undertaken steps to plan for or prepare for disasters. Thus, efforts are needed by educational institutions to develop the youth's knowledge on disaster management and improve their attitude towards the importance of preparedness. Research 
has shown that youth disaster preparedness education is an essential step in building and maintaining resilient communities (FEMA, 2013).

Youths of today must be empowered through education to provide them with the knowledge to cope with the adverse effects of natural disasters as well as assist each other. Educating the youth helps them brace a community for incoming disasters. When educated, they can fully understand what to expect and how to cope when disaster strikes (De la Vega, 2004). Education will lower the youth's vulnerability and improve their resilience during these events. For maximum impact, education for sustainability is more important. This is the use of education to achieve sustainability by providing them with the knowledge and skills needed to help them cope with environmental issues and implement sustainable development. This will also develop their capacity to manage crises and prepare for future emergencies (De la Vega, 2004).

Early engagement of young people in planning and preparedness efforts for disasters is also essential. This helps them understand the nature of society's response to disasters and how to reduce the risks of a disastrous event. It also provides them with practical knowledge and approaches to learning about disaster preparedness (Borum, et al., 2010; Khorram-Manesh, 2015).

For example, in India and Sri Lanka, schoolchildren were taught to rescue their friends from the beach during a disaster, treat injuries by bandaging fake wounds, and identify safe evacuation routes (Nikku, 2008). Plan International established children's DRR clubs in El-Salvador after several hurricanes and earthquakes. These clubs help them learn about DRR risks and how to protect their friends when disaster strikes. In Jamaica, school children participated in a cooking competition that used only food that would be available after a disaster (Peek, 2008).

Being aware of an impending disaster reduces $50 \%$ of losses due to disaster. Thus, awareness among the young generation through various initiatives has been the main focus of disaster management programs. Community-Based Disaster Preparedness, which involves the youth, is the best form of disaster preparedness as it advocates for a bottoms-up approach in disaster management. It is an acknowledged fact that whatever the level of readiness at the top level, it takes 24 to 48 hours to reach a community in its normal condition. In the case of severe disasters, however, this period may vary. Hence, the wise approach is to train the youth who are a part of the community in rescue operations, first aid, and psychological first aid for self-reliance. To build up the community's repertoire of skills, the selected youths of the village should be imparted with training in chosen subjects (UNDP India, 2002) in the stages of preparedness, response, and rehabilitation.

Volunteerism is another vital strategy to involve youth in disaster risk management. It allows youth to be a part of development activities. They gain a sense of ownership and a deeper understanding of their issues and rights. They also develop skills that provide them with better opportunities to address development goals and meet development issues head-on (Olivier, 2017). Youth volunteers can be engaged during different phases of disaster risk reduction, which will help in reinforcing the strategies outlined to manage disasters (Ministry of Youth Affairs and Sports, Government of India, 2017a).

\section{Case Studies}

\section{Earthquake in Ranau, Sabah}

Asia Pacific countries are the most vulnerable for geological hazards such as earthquake and other disasters (Shaful \& Ahmadun, 2006), and Malaysia is not spared anymore even though the country 
sits outside of the pacific ring of fire (Marto, Kasim, Soon, Zurairahetty, \& Yunus, 2013). Thus, there have been few cases recorded, such as the 5.9 magnitudes of the Ranau earthquake in 2015 killed 18 climbers, and 3.2 magnitudes of the Bukit Tinggi earthquake in 2007 (Majid, Adnan, Adiyanto, Ramli, \& Ghuan, 2017; Tongkul, 2017). By referring to this case, its shows that Malaysia still lacks in public awareness programs, disaster warning systems and earthquake subjects offered in secondary or higher education (Adnan et al., 2015).

Therefore, the preparedness measures should be formulated to reduce the total loss (Taghizadeh, et al., 2012) because some disaster might not only emerge from this country but also from nearby countries such as the 2004 Sumatran earthquake where 68 people died in Malaysia (Adnan et al., 2015).

In Malaysia, one of the studies on earthquake was conducted by Joanita and Haliza in 2018. These studies were done by distributing questionnaires that have been modified from Taghizadeh et al., 2012. It consists of 5 sections with 53 questions altogether. A pre-test was done on the questionnaire, with $10 \%$ of the number of the exact sample size $(n=11)$. The Cronbach alpha obtained was 0.73 . A cross-sectional questionnaire survey was conducted in Ranau, Sabah, between JanuaryFebruary 2019.

Ranau is a rural district in Sabah located on the Southern flank of the magnificent Mount Kinabalu (4,101m). The area is one of the most active seismic activity in Malaysia (Indan, Roslee, Tongkul, \& Simon, 2018). Five villages were chosen and identified as the study location; Kampung Dumpiring Atas, Dumpiring Bawah, Kundasang Lama, Lembah Permai, and Mesilou (Kamarudin et al., 2016). Hence, the questionnaires were distributed among the community in that particular villages through convenient sampling. In total, 106 respondents were involved (sample calculation was based on Slovin's,1960).

Therefore, the result from the questionnaire analysis found that most of the respondents were in the category of youth, age 15-30 years old, with a total of 46 (44.2\%) respondents. A total of $87(83.7 \%)$ of them stayed in Ranau for ten years and above, and most of them have been living there since birth. The last socio-demographic characteristic is the prior experience of an earthquake where $6(5.8 \%)$ respondents have experienced an earthquake once, and 88 (84.6\%) of them have felt the quake for three times or more. The level KAP on the earthquake preparedness is at moderate of 49 $(47.1 \%), 77(74 \%)$, and $69(66.3 \%)$, respectively. The knowledge level of the respondents overall is moderate. The people of Ranau might have information about the disaster, but they have less exposure to the specific detail about it. The level of attitude among the respondents is at a moderate of $74 \%$. In Malaysia, since the earthquake is a rare disaster, the awareness program, disaster warning system, and subjects related to an earthquake is still far from a deep implementation to the public (Adnan et al., 2015). Hence, the preparedness practice on earthquake based on the result is also at a moderate level of $66.3 \%$.

\section{Haze in Malaysia}

Nor Hazwani and Haliza did this study in 2018, which focuses on haze. Haze is one of the atmospheric pollutions that has occurred in Malaysia. Most of the haze episodes occurred in conjunction with a period of prolonged drought associated with the El Nino phenomenon. Haze has tremendous negative impacts in terms of health, social, and economy. Thus, in the second case study, the research is focused on the comparison of knowledge, attitude, and practice on haze among first and final year 
medical students. The course aims to know the experience, philosophy and practice on haze among the first and final year of medical students in Universiti Putra Malaysia (UPM). In this cross-sectional study, a total of 244 students were involved as respondents. The result showed that the level of knowledge for the first and final year of medical students was moderate, which was 40(41.9\%) and $59(39.1 \%)$, respectively. The level of attitude for both groups was also average, which was 54(57\%) and $97(64.2 \%)$, respectively. For the practice level, both groups showed bad practice during the haze, which was $64(68.8 \%)$ and $107(70.9 \%)$. The findings also indicated that there was no significant difference in mean knowledge, attitude, and practice on haze between these two groups ( $Z=0.555$, $p>0.05 ; t=-1.573 . p>0.05 ; Z=-0.720, p>0.05)$. Malay and Chinese students were associated with knowledge level with an odds ratio (OR) 5.22 and 2.98, respectively. Besides, there was an association between knowledge and practice $(p=0.003, p<0.005)$. The attitude level was associated with a practice level in which a moderate attitude tends to have inadequate training on haze $(p=0.024$, $p<0.05)$. Overall, the medical student's perceived reasonable knowledge and attitude but low in practice.

\section{Malaysia's Efforts to Involve Youth in Disaster Risk Management}

In Malaysia, the World Youth Foundation, in cooperation with the UNEP, Emirates Diving Association, UAE, Asian Disaster Preparedness Centre, Thailand, Ministry of Youth \& Sports Malaysia, Ministry of Natural Resources \& Environment Malaysia, Economic Planning Unit of the Prime Minister's Department, Malaysia, the State Government of Melaka and various other agencies hosted the International Training Workshop for Youth Representatives On Environment and Disaster Management from 19th - 23rd August 2006 in Melaka.

This international training workshop was a follow-up to the International Conference on Environment and Disaster Management held in Melaka, Malaysia, from 26 - 29th August 2005, where the conference participants collectively adopted the Malacca Youth Declaration on Sustainable Development of Environment \& Disaster Management. The idea of participation was based on the conviction that young people themselves are the best resources for promoting their development. In this new millennium, they can help to meet the challenges of the world's burgeoning environmental problems.

There are many other initiatives by the government, research institutes, and nongovernmental agencies such as Mercy Malaysia that promote DRR to the young generation through education and extra-curricular activities like DRR and emergency-related drills (Lam and Huang, 2018).

Additionally, the Ministry of Education developed policies on School Emergency Preparedness and Response Programs. In 2010, an Emergency Preparedness Handbook was developed and distributed to school children. A Smart Support Team (SST) was also initiated to address the psychological and educational needs of children who were disaster victims (Lam and Huang, 2018). The mandate to expand these programs to respond to disasters was given to the National Security Council, Department of Social Welfare, Malaysian Red Crescent, and the Malaysian Medical Relief Society (MERCY Malaysia). In the same year, SST leaders from the districts were trained together with 400 volunteers on Basic Mission Training (BMT) by MERCY Malaysia to prepare them for humanitarian relief missions (Wan, 2015). 
Moreover, CIMB Foundation, in collaboration with Universiti Kebangsaan Malaysia (UKM), hosts a three-day event for youths on understanding and preparing for disasters. Undergraduates from Brunei, Cambodia, Indonesia, Laos, Malaysia, Myanmar, the Philippines, Singapore, Thailand, and Vietnam take part. The workshop is part of the CIMB Foundation's Young ASEAN Leaders (CIMB $\mathrm{YAL}$ ) program aimed at training young leaders on social responsibility and inspiring them to initiate programs to benefit their respective communities. The 2016 theme focused on mitigating the risks of disasters through systematic analysis and proper risk management through reducing exposure to hazards, adequate land, and environment management, and improved preparedness to lessen the vulnerability of people and the impact of disasters on property.

Also, Malaysia provides the impetus for social innovation by facilitating the development of community-level disaster resilience plans to empower special groups, including women and youth, to participate in disaster risk reduction.

\section{Conclusion}

Repeated disasters threaten sustainable development. Thus, disaster preparedness and mitigation measures are very crucial in preventing human misery and economic hardship. Holistic Disaster management necessitates a multi-stakeholder approach involving all segments of society, including youth. This is very crucial because the large youth population constitutes a vibrant and dynamic segment of the country's population and is potentially the most valuable human resource in facilitating community plans to cope with disasters.

For that reason, youth is an essential part of the overall community disaster awareness and preparedness process. Youths as well are future decision-makers, who may encounter a significant disaster event in their lifetime and need to be educated on ways to prepare for disasters. Educational interventions among them may help increase awareness and preparedness of parents and, subsequently, the local community (Gulay, 2010).

However, educating, creating awareness, involving, and strengthening the capacity of youth in disaster risk management is the most challenging part. Hence, the approach of youth-based disaster preparedness, especially capacity building by conducting meetings, workshops, seminars, training camps for sensitization, knowledge dissemination, and developing skill sets are the best form of disaster preparedness among youth as these advocates for a bottoms-up approach on disaster management. With this approach, youths could be key players in preparing the community for selfreliance, self-help, and self-protection to reduce the losses caused by disasters.

\section{Acknowledgement}

The author would like to thank Universiti Putra Malaysia for providing a research grant (9661300) that made this study successful.

\section{References}

Aini, M. S., \& Fakhru'I-Razi, A. (2017). Disaster Management: Lessons from Man-Made Disasters. Serdang: Universiti Putra Malaysia Press.

Ali, M. S. S. M., Arsyad, A., Kamaluddin, N., Busthanul, \& Dirpan, A. (2019). Community Based Disaster Management: Indonesian Experience. P. 012012 in Vol. 235. IOP Publishing. 
Bartlett, S. (2008). After the Tsunami in Cooks Nagar: The Challenges of Participatory Rebuilding. Children, Youth and Environments 18(1):470-84.

Castro, R. (2013). Disaster Risk Reduction and Management.

Cebu, M. (2015). The Youth's Role in Disaster Risk Reduction and Management. Retrieved 15 March 2020. https://megacebu2050.wordpress.com/2015/07/06/the-youths-role-in-disaster-riskre duction-and-management/.

De, L. V., \& Rodrigo, M. C. L. (2004). Awareness, Knowledge, And Attitude About Environmental Education: Resp. Unniversity of Central Florida.

Finnis, K. K., David, M., Johnston, Kevin, R., Ronan, \& James, D. W. (2010). Hazard Perceptions and Preparedness of Taranaki Youth. Disaster Prevention and Management: An International Journal.

Gulay, H. (2010). An Earthquake Education Program with Parent Participation for Preschool Children. Educational Research and Reviews 5(10):624.

Ghani, M. F. A., \& Shahdan, T. N. T. (2016). Analysis of Staff Academic Working Competencies in Malaysian Private Universities. International Journal of Academic Research in Public Policy and Governace, 3(1), 44-52.

Henry, R., \& Gireesan, K. (2011). Role of Youth in Community Based Disaster Management. Role of Youth in Community Based Disaster Management. India: Knowledge Hub.

IFRC. (2011). 'Why the World's Youth Are Key to Reducing the Impact of Disasters'. Retrieved 22 March 2020. https://www.ifrc.org/en/news-and-media/opinions-and-positions/opinionpieces/ 2011/international-day-for-disaster-reduction-why-the-worlds-youth-are-key-toreducing- the-impacts-of-disasters-/.

Joanita, J., \& Haliza, A., R. (2018). Community knowledge, Attitude and practice on the preparedness of Earthquake Disaster in Ranau, Sabah. Final Year Project of Bachelor of Health Sciences (Environmental \& Occupational Health). Universiti Putra Malaysia.

Khorram-Manesh, A. (2015). Training in Disaster Medicine and Emergencies. A Short Review. Journal of Emergency and Critical Care Medicine 2(4):1024.

Khorram-Manesh, A., Olivera, L., Tom, F., Gotz, A., Kubilay, K., Ahmadreza, R., Djalali, Marco, F., Pier, L. I., Michael, A., \& Chris, A. (2016). Education in Disaster Management: What Do We Offer and What Do We Need? Proposing a New Global Program. Disaster Medicine and Public Health Preparedness 10(6):854-73.

Laili, Y., Asmah, Siti, A., John, A., Rozita, A., Zainal, A. A., Alias, A., \& Safiah, S. (2016). Youth Knowledge on the Law of Youth Development in Malaysia'. International Journal of Social Science and Humanity 6(5):336-40.

Lam, F. S., \& Yuk, F. H. (2018). Enhancing Disaster Preparedness through Participatory Activities in a School in Malaysia. (05):11.

Ministry of Youth Affairs and Sports, Government of India. (2017). Promoting Social Inclusion of Excluded Youth Groups.

Nikku, B. R. (2008). Children as Actors in Disaster Management: Insights from a South Asia Regional Research Study. Women's Career Advancement and Training \& Development in the 594.

Nor, H. M. N., \& Haliza, A. R. (2018). Comparison of knowledge, attitude and practice on haze among first and final year medical students in Universiti Putra Malaysia. Asian J. Agriculture \& Biology. Special Issue: 46-54. (Scopus). 
Oddsdóttir, Freyja, B. L., \& Emilie, C. (2013). Measuring Disaster Resilience. 12.

Peek, L. (2008). Children and Disasters: Understanding Vulnerability, Developing Capacities, and Promoting Resilience-An Introduction. Children Youth and Environments 18(1):1-29.

ReliefWeb. (2019). 'Malaysia: Disaster Management Reference Handbook (June 2019) - Malaysia'. ReliefWeb. Retrieved 22 March 2020. https://reliefweb.int/report/malaysia/malaysiadisaster-management-reference-handbook-june-2019.

Ronan, Kevin, R., Eva, A., Briony, T., Victoria, A., Johnson, \& David, M. J. (2015). Disaster Preparedness for Children and Families: A Critical Review'. Current Psychiatry Reports 17(7):58.

UNDP India. (2002). Good Practices in Community Based Disaster Risk Management. GOI-UNDP Disaster Risk Management Programme (2002-2009).

UNEP. (2017). Environment and Youth Engagement.

UNESCO. (2019). By Youth, with Youth, for Youth. UNESCO. Retrieved 22 March 2020 (https://en.unesco.org/youth).

UNISDR. (2011). Hyogo Framework for Action 2005-2015. Building the Resilience of Nations and Communities to Disasters. Mid Term Review 2010-2011.'

UNISDR. (2015). Sendai Framework for Disaster Risk Reduction 2015 - 2030'.

United Nations. (2002). Youth in Malaysia; A Review of the Youth Situation and National Policies and Programmes.

United Nations. (2019). 'World Population Prospects - Population Division'. UN Department of Economic and Social Affairs. Retrieved 22 March 2020 https://population.un.org/wpp/ Download/Standard/Population/.

Wan, Z. N. (2015). Age and Motives for Volunteering: From Socioemotional Selectivity Theory Perspective'. in Proceedings of the Academic Symposium of Social Science. Universiti Teknologi MARA Kelantan.

Zurairi, A. R. (2018). Climate-Related Natural Disasters Cost Malaysia RM8b in Last 20 Years. Malay Mail. 